\title{
ANALISIS PENERAPAN METODE CONVEX HULL DAN CONVEXITY DEFECTS UNTUK PENGENALAN ISYARAT TANGAN
}

\author{
Artha Gilang Saputra ${ }^{1}$, Ema Utami ${ }^{2}$ dan Hanif Al Fatta ${ }^{3}$ \\ 1, 2,3) Magister Teknik Informatika, Universitas Amikom Yogyakarta \\ Jl. Ring Road Utara, Condong Catur, Sleman, Yogyakarta, Indonesia 55281 \\ Email : artha.gilang01@gmail.com,ema.u@amikom.ac.id, hanif.a@amikom.ac.id
}

\section{ABSTRACT}

Research of Human Computer Interaction (HCI) and Computer Vision (CV) is increasingly focused on input device problem to interact with computer. The main purpose of this research is to applying the Convex Hull and Convexity Defects methods for Hand Gesture Recognition system.

In this research, the Hand Gesture Recognition system designed with the OpenCV library and then receives input from the user's hand gesture using an integrated webcam on the computer and system generates a language output from the hand-recognizable gestures.

Testing involves several variables which affect success in recognizing user's hand gestures. As a result, the user's hand gestures can be recognized with a stable and accurate when at a distance of $50 \mathrm{~cm}-70 \mathrm{~cm}$, corner of the finger $25^{\circ}-70^{\circ}$, light conditions 150lux-460lux and plain background conditions.

Keyword : Computer Vision, Convex Hull, Convexity Defects, Hand Gesture Recognition, Human Computer Interaction

\section{PENDAHULUAN}

Penelitian terbaru dalam human computer interaction dan computer vision semakin berfokus pada membangun sistem untuk mengamati manusia dan memahami pandangan, aktivitas, dan perilaku manusia yang menyediakan antarmuka canggih untuk berinteraksi dengan manusia, dan menciptakan model sistem yang digunakan manusia yang masuk akal untuk berbagai tujuan. Agar salah satu dari sistem ini berfungsi, peneliti memerlukan metode untuk mendeteksi objek dari gambar atau video yang diberikan. Analisis visual gerak manusia saat ini merupakan salah satu topik penelitian yang paling aktif dalam computer vision. Pendeteksian tubuh manusia yang bergerak adalah bagian terpenting dari analisis gerak tubuh manusia, tujuannya adalah untuk mendeteksi tubuh manusia yang bergerak dari gambar latar belakang dalam rangkaian video dan untuk digunakan dalam bidang pengobatan seperti klasifikasi target, pelacakan 
tubuh manusia dan pemahaman perilaku (Rakibe dan Patil, 2013).

Penelitian mengenai Human Computer Interaction (HCI) terus mengalami perkembangan, terutama untuk permasalahan perangkat masukan (input device) yang digunakan untuk berinteraksi dengan komputer. Perangkat mekanis seperti mouse, joystick, trackball, touchscreen, touchpad, pointing stick, light pen, digitizer dan footmouse merupakan perangkat input yang digunakan dalam mengoperasikan dan mengeksekusi perintah komputer. Saat ini, mouse, keyboard dan joystick merupakan perangkat yang dominan dan umum digunakan pengguna komputer. Walaupun banyak digunakan, sebenarnya perangkat masukan tersebut memiliki beberapa kelemahan, salah satu diantaranya adalah tidak alami bagi manusia. Hal ini disebabkan karena manusia sudah terbiasa berkomunikasi dengan sesama manusia menggunakan media komunikasi suara disertai bentuk gerakan tubuh (body pose) dan isyarat tangan (hand gesture).

Penggunaan hand gesture memiliki beberapa kelebihan dibanding perangkat masukan konvensional seperti mouse atau keyboard, yaitu dalam hal banyaknya variasi masukan yang dapat dilakukan, lebih mudah dilakukan, lebih alami, lebih interaktif dan membutuhkan proses pembelajaran yang relatif lebih singkat. Sebuah sistem pengenalan hand gesture dapat dibagi menjadi dua tahap, yaitu tahap akuisisi hand gesture dan tahap pengenalan (recognition). Tahap akuisisi merupakan proses untuk mendapatkan pola hand gesture yang dilakukan oleh pengguna sistem tersebut. Untuk hand gesture dinamis tahapannya terdiri dari hand detection, hand segmentation dan hand tracking. Pada tahap pengenalan dilakukan proses identifikasi atau proses pengelompokkan (clustering) untuk menginterpretasikan hand gesture yang didapatkan dari tahap akuisisi (Lukito, 2013).

Penelitian ini dimaksudkan untuk menganalisis penerapan metode Convex Hull dan Convexity Defects ke dalam model sistem hand gesture recognition atau pengenalan isyarat tangan sebagai bentuk interaksi antara manusia dan komputer.

\section{METODE}

Pada metode Convex Hull terdapat convex polygon yaitu sebuah polygon yang tidak memiliki bagian yang cekung (concave). Jika dipilih dua 
titik yang mana saja dari sebuah polygon (termasuk pada sisi-sisinya dan area yang ditutupi oleh sisi-sisinya) dan dua titik tersebut dihubungkan dengan sebuah garis lurus. Jika semua garis lurus yang dapat dibentuk dari dua titik di dalam polygon tidak melewati batas polygon maka polygon tersebut bisa disebut convex polygon. Untuk sekumpulan titik pada sebuah bidang, convex hull dari kumpulan titik tersebut adalah convex polygon terkecil yang mengelilingi semua titik pada kumpulan titik tersebut. Sebagai contoh, pada gambar 1 terdapat 10 titik, segi enam pada gambar tersebut adalah convex hull dari kumpulan titik tersebut. Enam titik yang membentuk segi enam disebut "hull points" (Chen, 2011).

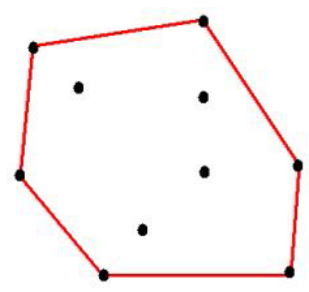

Gambar 1 Contoh Convex Hull (Muqtadir dkk., 2016).

Metode Convexity Defect menyediakan informasi yang sangat berguna untuk memahami bentuk kontur. Banyak karakteristik dari kontur yang rumit dapat digambarkan dengan convexity defect. Gambar 2 menggambarkan convexity defect dari bidang yang berbentuk bintang, garis hijau mewakili convex hullnya. Seperti yang dapat dilihat pada gambar 2, area yang berwarna kuning berada di dalam convex hull tapi tidak berada di dalam bintang. Area tersebut disebut dengan convexity defect (Chen, 2011).

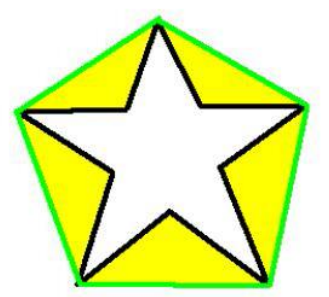

Gambar 2 Area yang berwarna kuning mewakili convexity defect (Muqtadir dkk., 2016).

Jenis metode penelitian yang dilakukan penulis adalah Eksperimen. Eksperimen adalah suatu cara untuk mencari hubungan sebab akibat (causal effect) antara dua faktor yang sengaja ditimbulkan oleh peneliti dengan mengeliminasi atau mengurangi atau menyisihkan faktor-faktor lain yang bisa mengganggu. Eksperimen selalu dilakukan dengan maksud untuk melihat akibat dari suatu perlakuan yang dilakukan oleh peneliti (Arikunto, 2002). Eksperimen yang dilakukan adalah eksperimen mengenai metode convex hull dan convexity defect terhadap keakuratan dalam mengenali perintah gerakan tangan. Penelitian ini menggunakan objek satu tangan 
pengguna yang kemudian convex hull untuk mendeteksi ujung jari dan convexity defect untuk mendeteksi jarak antara jari.

Penelitian ini menerapkan sifat penelitian Kausal. Penelitian Kausal yaitu hubungan yang bersifat sebab akibat. Tujuan utama dari penelitian kausal ini adalah untuk mendapatkan bukti hubungan sebab akibat, sehingga dapat diketahui mana yang menjadi variabel yang mempengaruhi dan mana variabel yang dipengaruhi (Sugiyono, 2012). Dalam penelitian ini, penulis bertujuan untuk menganalisis variabel metode convex hull dan convexity defects terhadap keakuratan dalam pengenalan isyarat tangan sesuai perintah yang dikeluarkan. Proses ini melibatkan satu tangan pengguna yang kemudian direkam melalui webcam terintegrasi. Variabel jarak, kondisi cahaya, sudut jari dan background juga turut menentukan keberhasilan dalam mendeteksi isyarat tangan sehingga perintah yang dikeluarkan benar dan sesuai.

Pendekatan penelitian yang diterapkan pada penelitian ini adalah Pendekatan Kuantitatif. Penelitian ini berfokus pada keakuratan dalam mengenali isyarat tangan menggunakan webcam yang telah diberi perintah menggunakan convex hull dan convexity defect. Keberhasilan dalam mendeteksi dan mengenali isyarat tangan tersebut akan dilakukan melalui beberapa skenario sehingga akan didapatkan data rekomendasi yang paling sesuai untuk proses mengenali isyarat tangan pengguna dalam sebuah tabel hasil pengujian. Tahapan dalam penelitian ini dapat dilihat pada gambar 3 .

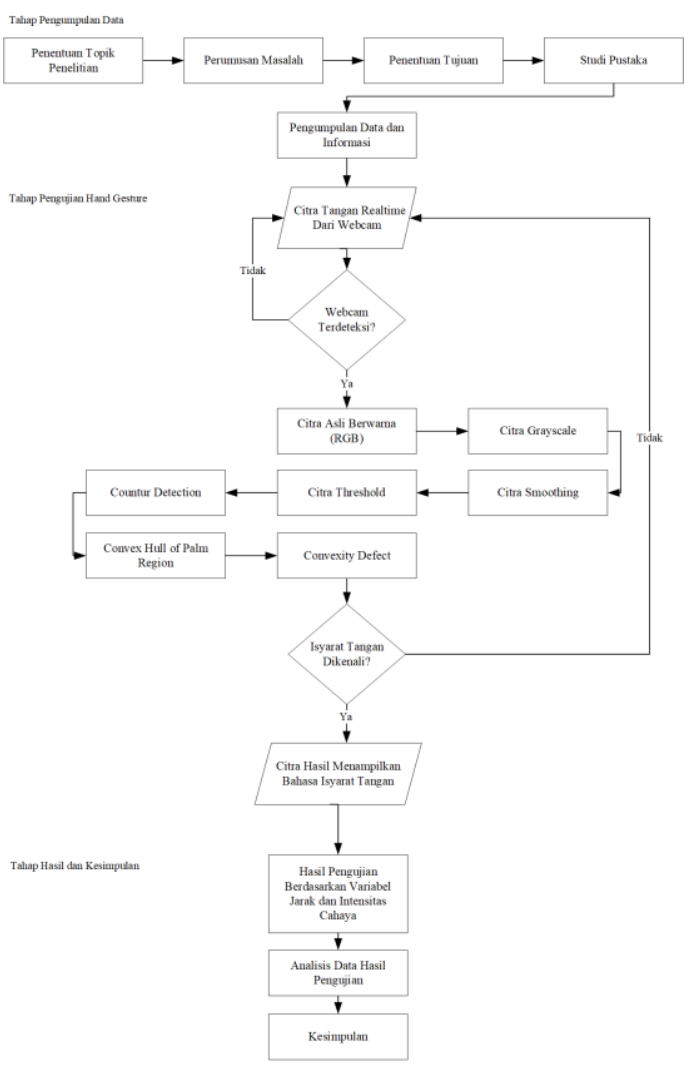

Gambar 3 Alur penelitian pada pengenalan isyarat tangan menggunakan metode convex hull dan convexity defects.

\section{HASIL DAN PEMBAHASAN}

Pada tahap ini akan dijelaskan analisis kinerja dari Hand Gesture 
Recognition. Secara singkat, pada pemrosesan citra terdapat beberapa langkah yaitu pertama melakukan threshold terhadap citra asli dari tangan pengguna. Kemudian sistem dapat melakukan threshold dengan sempurna jika terdapat cahaya yang cukup terang di depan pengguna sehingga hasil threshold hanya menampilkan telapak tangan. Kemudian langkah kedua yaitu memilih kontur yang terbesar di antara semua kontur. Setelah area tersebut ditemukan (tentunya berupa area tangan jika hasil threshold cukup baik), maka akan ditandai dengan garis berwarna kuning dan biru muda pada setiap sisi nya. Langkah ketiga adalah proses pencarian Convex Hull dan Convexity Defect. Jika Convex Hull dan Convexity Defect telah ditemukan, maka langkah selanjutnya adalah mengenali hand gesture dari pengguna yaitu berupa jumlah jari tangan yang diperlihatkan oleh pengguna.

\section{Proses hand gesture recognition}

Proses hand gesture recognition secara detail adalah sebagai berikut.

\section{Proses Capture Citra RGB.}

Tahap awal adalah proses menangkap citra tangan pengguna menggunakan webcam berupa video capture secara realtime. Sistem dapat memberikan status webcam apakah berjalan baik atau terdapat masalah dalam menangkap citra. Citra tangan yang berhasil dideteksi webcam dapat dilihat pada gambar 4 .

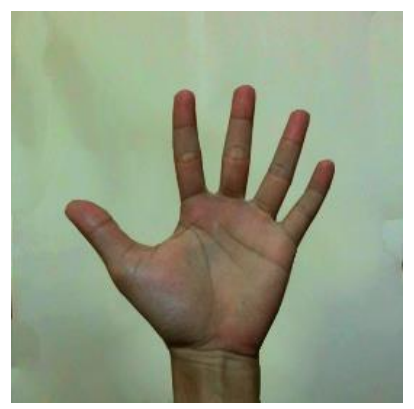

Gambar 4 Citra tangan $(R G B)$ yang berhasil dideteksi webcam.

\section{Proses Konversi Citra RGB - Grayscale.}

Tahap kedua, setelah webcam berhasil terdeteksi maka citra video realtime dari tangan pengguna berupa citra tangan yang memiliki warna asli $(R G B)$ akan dikonversi menjadi citra abu-abu (Grayscale).

\section{Proses Citra Smoothing.}

Tahap ketiga, citra tangan grayscale tersebut diperhalus (Smoothing) yang berfungsi mengurangi noise dari proses capture. Peran OpenCV juga turut membantu dalam proses smoothing tersebut. Bentuk citra tangan grayscale dan smoothing dapat dilihat pada gambar 5 . 


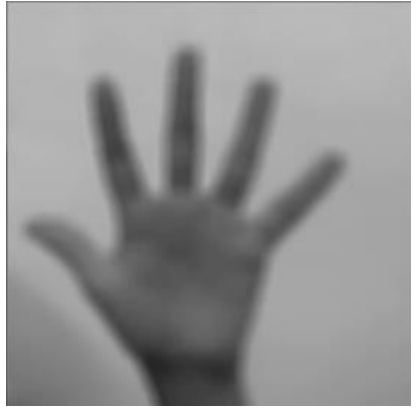

Gambar 5 Citra tangan setelah proses grayscale dan smoothing.

\section{Proses Citra Threshold.}

Tahap keempat, proses yang dilakukan adalah thresholding.

Thresholding berfungsi memisahkan antara objek dengan background dalam suatu citra berdasarkan pada perbedaan tingkat kecerahannya atau gelap terangnya. Bentuk citra tangan thresholding dapat dilihat pada gambar 6.

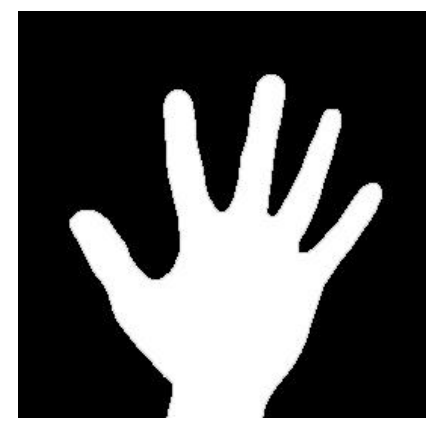

Gambar 6 Citra tangan yang telah mengalami proses thresholding.

\section{Proses Deteksi Countur.}

Tahap kelima, proses selanjutnya adalah mendeteksi kontur telapak dan jari tangan yang kemudian akan digunakan untuk proses Convex Hull dan Convexity Defects sehingga dapat dideteksi bentuk tangan pengguna.

\section{Proses Deteksi Convex Hull dan Convexity Defects.}

Tahap keenam, proses yang dilakukan selanjutnya adalah mencari titik puncak dari jari tangan pengguna (titik puncak convex) dan titik dari selasela jari tangan (titik depth), setelah titik-titik puncak convex telah ditemukan, maka convex hull dapat dibentuk dengan menghubungkan titiktitik convex tersebut. Pada penelitian ini, Convex Hull digambarkan searah jarum jam. Kemudian, setelah Convex Hull terdeteksi, proses selanjutnya adalah pencarian area yang masuk pada Convex Hull tetapi tidak berada di dalam objek tangan pengguna (sela-sela jari tangan). Bentuk citra tangan setelah proses Convex Hull dan Convexity Defects dapat dilihat pada gambar 7 .

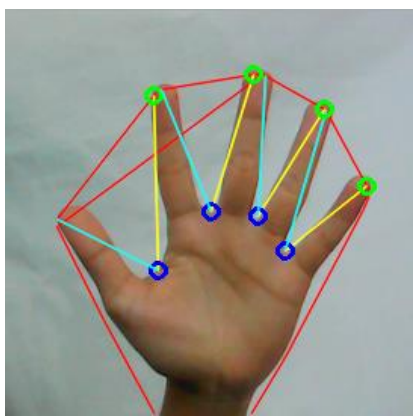

Gambar 7 Citra tangan yang telah diproses oleh Convex Hull dan Convexity Defects.

\section{Proses Pengenalan Hand Gesture.}

Tahap akhir, mengenali dan menampilkan output dari setiap hand 
gesture dari pengguna. Penulis membuat bahwa tangan yang menunjukkan 1 jari, lebih dari 5 jari dan tidak menunjukkan jari maka sistem didefinisikan tidak dapat mengenali hand gesture. Hand gesture yang dapat dikenali hanya tangan yang menunjukkan 2 sampai 5 jari tangan. Output pada masing-masing bentuk tangan dapat dilihat pada gambar 8 .

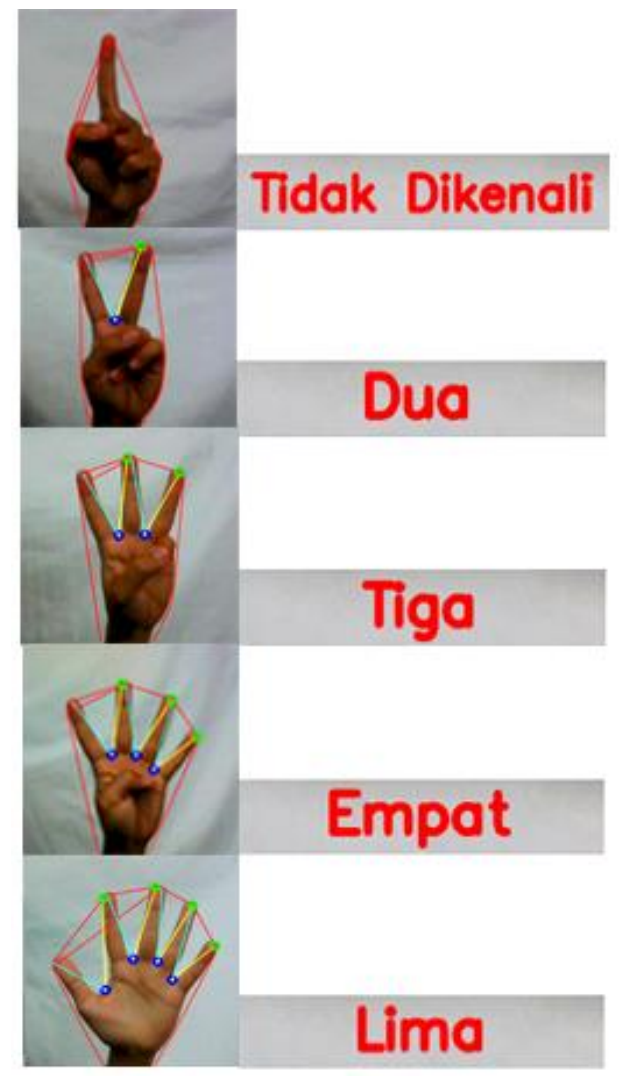

Gambar 8 Isyarat tangan dan hasil terjemahannya.

Variabel uji coba pada tahap pengujian yaitu tangan, alat pengukur jarak tangan dalam satuan centimeter $(\mathrm{cm})$, alat pengukur sudut jari tangan dalam satuan derajat $\left(^{\circ}\right)$ dan aplikasi sensor pengukur intensitas cahaya dalam satuan iluminasi (lux). Uji coba dilakukan untuk mengetahui apakah hand gesture (jumlah jari tangan) dari pengguna akan memberikan output yang sesuai dengan yang telah dirancang atau tidak, serta pengaruh background, jarak tangan pengguna dan kondisi cahaya oleh webcam terhadap deteksi hand gesture.

Pada tahap pengujian 1-8 dilakukan dengan bentuk isyarat tangan dengan menunjukkan/membuka jari 1 sampai 5 jari secara tegak dengan masing-masing terjemahannya yang akan diuji coba menggunakan jarak tangan dengan webcam berkisar antara $10 \mathrm{~cm}-100 \mathrm{~cm}$, sudut jari tangan berkisar antara $25^{\circ}-60^{\circ}$, sumber cahaya berasal dari cahaya lampu dalam ruangan, kondisi cahaya berkisar antara 30 lux - 160 lux dan kondisi background polos dan tidak polos.

\section{Skenario Pengujian}

\section{Skenario Pengujian 1.}

Uji coba dilakukan pada background yang polos, jarak tangan dari depan webcam normal yaitu $50 \mathrm{~cm}$ serta kondisi pencahayaan yang terang yaitu 152 lux. Hasil pengujian 1 dapat dilihat pada Tabel 1. 
Tabel 1 Data hasil pengujian skenario 1.

\begin{tabular}{|c|c|c|c|}
\hline No & $\begin{array}{c}\text { Jumlah } \\
\text { Jari }\end{array}$ & Output & Keterangan \\
\hline 1 & 1 & $\begin{array}{c}\text { Tidak } \\
\text { Dikenali }\end{array}$ & $\begin{array}{c}\text { Stabil } \\
\text { Akurat }\end{array}$ \\
\hline 2 & 2 & Dua & $\begin{array}{l}\text { Stabil } \\
\text { Akurat }\end{array}$ \\
\hline 3 & 3 & Tiga & $\begin{array}{l}\text { Stabil } \\
\text { Akurat }\end{array}$ \\
\hline 4 & 4 & Empat & $\begin{array}{l}\text { Stabil } \\
\text { Akurat }\end{array}$ \\
\hline 5 & 5 & Lima & $\begin{array}{l}\text { Stabil } \\
\text { Akurat }\end{array}$ \\
\hline
\end{tabular}

Pada skenario pengujian 1, deteksi hand gesture berjalan stabil dan akurat sesuai output pada semua hand gesture, hal ini disebabkan karena jarak dan kondisi cahaya yang dibutuhkan webcam tercukupi dan sesuai sehingga kontur tangan dapat dibentuk dengan sempurna dan terbedakan dengan background.

\section{Skenario Pengujian 2.}

Uji coba dilakukan pada latar belakang atau background dengan kondisi polos dan tidak sewarna dengan tangan pengguna, jarak tangan dari depan webcam normal yaitu $50 \mathrm{~cm}$ serta kondisi pencahayaan yang terang yaitu 154 lux, tetapi ada objek berupa buku yang memiliki warna sama dengan tangan pengguna ketika terkena cahaya untuk melihat pengaruh pada hasil pengujian. Hasil pengujian 2 dapat dilihat pada Tabel 2 .
Tabel 2 Data hasil pengujian skenario 2.

\begin{tabular}{|c|c|c|c|}
\hline No & Jumlah Jari & Output & Keterangan \\
\hline 1 & 1 & $\begin{array}{c}\text { Tidak } \\
\text { Dikenali }\end{array}$ & $\begin{array}{c}\text { Tak Stabil } \\
\text { Tak Akurat }\end{array}$ \\
\hline 2 & 2 & Dua & $\begin{array}{c}\text { Tak Stabil } \\
\text { Tak Akurat }\end{array}$ \\
\hline 3 & 3 & Tiga & $\begin{array}{c}\text { Tak Stabil } \\
\text { Tak Akurat }\end{array}$ \\
\hline 4 & 4 & Empat & $\begin{array}{c}\text { Tak Stabil } \\
\text { Tak Akurat }\end{array}$ \\
\hline 5 & 5 & Lima & $\begin{array}{c}\text { Tak Stabil } \\
\text { Tak Akurat }\end{array}$ \\
\hline
\end{tabular}

Pada skenario pengujian 2, deteksi hand gesture berjalan tidak stabil dan tidak akurat sesuai output pada semua hand gesture, hal ini disebabkan karena objek tangan terganggu oleh objek lain (buku) sehingga kontur tangan tidak dapat dibentuk dengan sempurna.

\section{Skenario Pengujian 3.}

Uji coba dilakukan pada background yang polos, jarak tangan dari depan webcam normal yaitu $50 \mathrm{~cm}$ tetapi kondisi pencahayaan kurang terang yaitu 32 lux. Hasil pengujian 3 dapat dilihat pada Tabel 3 .

Tabel 3 Data hasil pengujian skenario 3.

\begin{tabular}{|c|c|c|c|}
\hline No & Jumlah Jari & Output & Keterangan \\
\hline 1 & 1 & $\begin{array}{c}\text { Tidak } \\
\text { Dikenali }\end{array}$ & $\begin{array}{c}\text { Tak Stabil } \\
\text { Tak Akurat }\end{array}$ \\
\hline 2 & 2 & Dua & $\begin{array}{c}\text { Tak Stabil } \\
\text { Tak Akurat }\end{array}$ \\
\hline 3 & 3 & Tiga & $\begin{array}{c}\text { Tidak Stabil } \\
\text { dan Tidak } \\
\text { Akurat }\end{array}$ \\
\hline 4 & 4 & Empat & $\begin{array}{c}\text { Tidak Stabil } \\
\text { dan Tidak } \\
\text { Akurat }\end{array}$ \\
\hline 5 & 5 & Lima & $\begin{array}{c}\text { Tidak Stabil } \\
\text { dan Tidak } \\
\text { Akurat }\end{array}$ \\
\hline
\end{tabular}


Pada skenario pengujian 3, deteksi hand gesture berjalan tidak stabil dan tidak akurat sesuai output pada semua hand gesture, hal ini disebabkan karena kurangnya kondisi cahaya yang dibutuhkan webcam sehingga kontur tangan tidak dapat dibentuk dengan sempurna.

\section{Skenario Pengujian 4.}

Uji coba dilakukan pada background yang tidak polos, jarak tangan normal dari depan webcam yaitu $50 \mathrm{~cm}$ dan kondisi pencahayaan kurang terang yaitu 31 lux. Hasil pengujian 4 dapat dilihat pada tabel 4 .

Tabel 4 Data hasil pengujian skenario 4 .

\begin{tabular}{|c|c|c|c|}
\hline No & Jumlah Jari & Output & Keterangan \\
\hline 1 & 1 & $\begin{array}{c}\text { Tidak } \\
\text { Dikenali }\end{array}$ & $\begin{array}{c}\text { Tak Stabil } \\
\text { Tak Akurat }\end{array}$ \\
\hline 2 & 2 & Dua & $\begin{array}{c}\text { Tak Stabil } \\
\text { Tak Akurat }\end{array}$ \\
\hline 3 & 3 & Tiga & $\begin{array}{c}\text { Tak Stabil } \\
\text { Tak Akurat }\end{array}$ \\
\hline 4 & 4 & Empat & $\begin{array}{c}\text { Tak Stabil } \\
\text { Tak Akurat }\end{array}$ \\
\hline 5 & 5 & Lima & $\begin{array}{c}\text { Tak Stabil } \\
\text { Tak Akurat }\end{array}$ \\
\hline
\end{tabular}

Pada skenario pengujian 4, deteksi hand gesture berjalan tidak stabil dan tidak akurat sesuai output pada semua hand gesture, hal ini disebabkan oleh background yang tidak polos dan kondisi cahaya yang kurang baik bagi webcam sehingga mengganggu kontur tangan tidak terbentuk dengan sempurna dan sulit terbedakan dengan background.

\section{Skenario Pengujian 5.}

Uji coba dilakukan pada jarak tangan cukup jauh dari depan webcam yaitu $70 \mathrm{~cm}$, background polos dan kondisi pencahayaan terang yaitu 152 lux. Hasil pengujian 5 dapat dilihat pada Tabel 5.

Tabel 5 Data hasil pengujian skenario 5.

\begin{tabular}{|c|c|c|c|}
\hline No & Jumlah Jari & Output & Keterangan \\
\hline 1 & 1 & $\begin{array}{c}\text { Tidak } \\
\text { Dikenali }\end{array}$ & $\begin{array}{c}\text { Stabil } \\
\text { Akurat }\end{array}$ \\
\hline 2 & 2 & Dua & $\begin{array}{c}\text { Stabil } \\
\text { Akurat }\end{array}$ \\
\hline 3 & 3 & Tiga & $\begin{array}{l}\text { Stabil } \\
\text { Akurat }\end{array}$ \\
\hline 4 & 4 & Empat & $\begin{array}{l}\text { Stabil } \\
\text { Akurat }\end{array}$ \\
\hline 5 & 5 & Lima & $\begin{array}{l}\text { Stabil } \\
\text { Akurat }\end{array}$ \\
\hline
\end{tabular}

Pada skenario pengujian 5, deteksi hand gesture berjalan stabil dan akurat sesuai output pada semua hand gesture, hal ini disebabkan karena jarak tangan masih dapat diterima oleh webcam dan sistem sehingga kontur tangan dapat dibentuk dengan sempurna dan terbedakan dengan background.

\section{Skenario Pengujian 6.}

Uji coba dilakukan pada jarak tangan pengguna jauh dari depan webcam yaitu $100 \mathrm{~cm}$, background dengan kondisi polos dan kondisi pencahayaan terang yaitu 153 lux. Hasil pengujian 6 dapat dilihat pada Tabel 6 . 
Tabel 6 Data hasil pengujian skenario 6 .

\begin{tabular}{|c|c|c|c|}
\hline No & Jumlah Jari & Output & Keterangan \\
\hline 1 & 1 & $\begin{array}{c}\text { Tidak } \\
\text { Dikenali }\end{array}$ & $\begin{array}{c}\text { Tak Stabil } \\
\text { Tak Akurat }\end{array}$ \\
\hline 2 & 2 & Dua & $\begin{array}{c}\text { Tak Stabil } \\
\text { Tak Akurat }\end{array}$ \\
\hline 3 & 3 & Tiga & $\begin{array}{c}\text { Tak Stabil } \\
\text { Tak Akurat }\end{array}$ \\
\hline 4 & 4 & Empat & $\begin{array}{c}\text { Tak Stabil } \\
\text { Tak Akurat }\end{array}$ \\
\hline 5 & 5 & Lima & $\begin{array}{c}\text { Tak Stabil } \\
\text { Tak Akurat }\end{array}$ \\
\hline \multicolumn{3}{|c|}{ Pada skenario pengujian 6, }
\end{tabular}

deteksi hand gesture berjalan tidak stabil dan tidak akurat sesuai output pada semua hand gesture, hal ini disebabkan karena jarak objek tangan terlampau jauh dari webcam sehingga kontur tangan tidak dapat dibentuk dengan sempurna.

\section{Skenario Pengujian 7.}

Uji coba dilakukan pada jarak tangan dekat dari depan webcam yaitu $10 \mathrm{~cm}$, background polos dan kondisi pencahayaan terang yaitu 153 lux. Hasil pengujian 7 dapat dilihat pada Tabel 7 .

Tabel 7 Data hasil pengujian skenario 7.

\begin{tabular}{|c|c|c|c|}
\hline No & Jumlah Jari & Output & Keterangan \\
\hline 1 & 1 & $\begin{array}{c}\text { Tidak } \\
\text { Dikenali }\end{array}$ & $\begin{array}{c}\text { Tak Stabil } \\
\text { Tak Akurat }\end{array}$ \\
\hline 2 & 2 & Dua & $\begin{array}{c}\text { Tak Stabil } \\
\text { Tak Akurat }\end{array}$ \\
\hline 3 & 3 & Tiga & $\begin{array}{c}\text { Tak Stabil } \\
\text { Tak Akurat }\end{array}$ \\
\hline 4 & 4 & Empat & $\begin{array}{c}\text { Tak Stabil } \\
\text { Tak Akurat }\end{array}$ \\
\hline 5 & 5 & Lima & $\begin{array}{c}\text { Tak Stabil } \\
\text { Tak Akurat }\end{array}$ \\
\hline \multicolumn{3}{|c|}{ Pada skenario pengujian 7, }
\end{tabular}

deteksi hand gesture berjalan tidak stabil dan tidak akurat sesuai output pada semua hand gesture, hal ini disebabkan karena jarak objek tangan pengguna terlalu dekat dengan webcam sehingga kontur tangan tidak dapat dibentuk dengan sempurna.

\section{Skenario Pengujian 8.}

Uji coba dilakukan pada jarak tangan normal dari depan webcam yaitu $50 \mathrm{~cm}$, background polos dan kondisi pencahayaan yang terlalu terang yaitu 460 lux. Hasil pengujian 8 dapat dilihat pada Tabel 8.

Tabel 8 Data hasil pengujian skenario 8 .

\begin{tabular}{|c|c|c|c|}
\hline No & Jumlah Jari & Output & Keterangan \\
\hline 1 & 1 & $\begin{array}{c}\text { Tidak } \\
\text { Dikenali }\end{array}$ & $\begin{array}{l}\text { Stabil } \\
\text { Akurat }\end{array}$ \\
\hline 2 & 2 & Dua & $\begin{array}{l}\text { Stabil } \\
\text { Akurat }\end{array}$ \\
\hline 3 & 3 & Tiga & $\begin{array}{l}\text { Stabil } \\
\text { Akurat }\end{array}$ \\
\hline 4 & 4 & Empat & $\begin{array}{l}\text { Stabil } \\
\text { Akurat } \\
\text { Stabil } \\
\text { Akurat }\end{array}$ \\
\hline
\end{tabular}

Pada skenario pengujian 8,

deteksi hand gesture berjalan stabil dan akurat sesuai output pada semua hand gesture, hal ini disebabkan karena kondisi cahaya yang sangat terang masih dapat diterima oleh webcam dan sistem sehingga kontur tangan dapat dibentuk dengan sempurna dan dapat terbedakan dengan background.

\section{Skenario Pengujian 9.}

Pada skenario pengujian 9, penulis menguji coba bentuk isyarat tangan dengan menunjukkan/membuka 
jari 1 sampai 5 jari namun dengan posisi menyamping kekiri. Variabel jarak, kondisi cahaya dan kondisi background hanya diuji pada satu kondisi tanpa variasi. Uji coba dilakukan pada background yang polos, jarak tangan dari depan webcam normal yaitu $50 \mathrm{~cm}$, sudut jari tangan berkisar antara $30^{\circ}-$ $70^{\circ}$, sumber cahaya berasal dari cahaya lampu dalam ruangan serta kondisi pencahayaan yang terang yaitu 150 lux. Hasil pengujian 9 dapat dilihat pada Tabel 9.

Tabel 9 Data hasil pengujian skenario 9.

\begin{tabular}{|c|c|c|c|}
\hline No & Jumlah Jari & Output & Keterangan \\
\hline 1 & 1 & $\begin{array}{c}\text { Tidak } \\
\text { Dikenali }\end{array}$ & $\begin{array}{c}\text { Stabil } \\
\text { Akurat }\end{array}$ \\
\hline 2 & 2 & Dua & $\begin{array}{l}\text { Stabil } \\
\text { Akurat }\end{array}$ \\
\hline 3 & 3 & Tiga & $\begin{array}{l}\text { Stabil } \\
\text { Akurat }\end{array}$ \\
\hline 4 & 4 & Empat & $\begin{array}{l}\text { Stabil } \\
\text { Akurat }\end{array}$ \\
\hline 5 & 5 & Lima & $\begin{array}{l}\text { Stabil } \\
\text { Akurat }\end{array}$ \\
\hline
\end{tabular}

Pada skenario pengujian 9, deteksi hand gesture berjalan stabil dan akurat sesuai output pada semua hand gesture, hal ini disebabkan karena jarak dan kondisi cahaya yang dibutuhkan webcam tercukupi dan sesuai sehingga kontur tangan dapat dibentuk dengan sempurna dan terbedakan dengan background. Selain itu, posisi tangan yang menyamping kekiri ternyata tidak mempengaruhi keberhasilan dalam mendeteksi bentuk isyarat tangan pengguna.

\section{Skenario Pengujian 10.}

Pada skenario pengujian 10 , penulis menguji coba bentuk isyarat tangan dengan menunjukkan jari 1 sampai 5 jari namun dengan posisi menutup rapat tanpa celah sela-sela jari (tidak terbentuk sudut jari tangan). Variabel jarak, kondisi cahaya, sudut dan kondisi latar belakang atau background hanya diuji pada satu kondisi tanpa variasi yaitu pada kondisi polos. Uji coba dilakukan pada latar belakang atau background yang polos, jarak tangan dari depan webcam normal yaitu $50 \mathrm{~cm}$, sudut jari tangan $0^{\circ}$, sumber cahaya berasal dari cahaya lampu dalam ruangan serta kondisi pencahayaan yang terang yaitu 151 lux. Hasil pengujian 10 dapat dilihat pada Tabel 10.

Tabel 10 Data hasil pengujian skenario 10.

\begin{tabular}{|c|c|c|c|}
\hline No & Jumlah Jari & Output & Keterangan \\
\hline 1 & 0 & $\begin{array}{c}\text { Tidak } \\
\text { Dikenali }\end{array}$ & $\begin{array}{c}\text { Stabil } \\
\text { Akurat }\end{array}$ \\
\hline 2 & 0 & Dua & $\begin{array}{c}\text { Stabil } \\
\text { Tak Akurat }\end{array}$ \\
\hline 3 & 0 & Tiga & $\begin{array}{c}\text { Stabil } \\
\text { Tak Akurat }\end{array}$ \\
\hline 4 & 0 & Empat & $\begin{array}{c}\text { Stabil } \\
\text { Tak Akurat }\end{array}$ \\
\hline 5 & 0 & Lima & $\begin{array}{c}\text { Stabil } \\
\text { Tak Akurat }\end{array}$ \\
\hline
\end{tabular}

Pada tabel hasil skenario

pengujian 10, deteksi hand gesture berjalan stabil dan akurat sesuai output 
pada nomor 1 dikarenakan tangan yang tidak membuka jari diterjemahkan sebagai bentuk yang tidak dikenali, sedangkan pada tangan yang menunjukkan 2 jari sampai 5 jari tidak dapat diterjemahkan dengan sempurna dikarenakan tidak adanya sudut pada sela - sela jari yang terbentuk sehingga convexity defects tidak dapat mendeteksi jumlah jari yang sebenarnya.

\section{Skenario Pengujian 11.}

Pada skenario pengujian 11, penulis menguji coba berbagai bentuk isyarat tangan dengan menunjukkan jari 1 sampai 4 jari namun dengan posisi acak. Variabel jarak, kondisi cahaya dan kondisi latar belakang atau background hanya diuji pada satu kondisi tanpa variasi. Uji coba dilakukan pada latar belakang atau background pada kondisi polos, jarak tangan dari depan webcam normal yaitu $50 \mathrm{~cm}$, sudut jari tangan yang terbuka berkisar antara $40^{\circ}-80^{\circ}$, sumber cahaya berasal dari cahaya lampu dalam ruangan serta kondisi pencahayaan yang terang yaitu 154 lux. Hasil pengujian 11 dapat dilihat pada Tabel 11.

Tabel 11 Data hasil pengujian skenario 11.

\begin{tabular}{|c|c|c|c|}
\hline No & Jumlah Jari & Output & Keterangan \\
\hline 1 & 1 (Ibu Jari) & $\begin{array}{c}\text { Tidak } \\
\text { Dikenali }\end{array}$ & $\begin{array}{c}\text { Stabil } \\
\text { Akurat }\end{array}$ \\
\hline
\end{tabular}

\begin{tabular}{|c|c|c|c|}
\hline 2 & $\begin{array}{c}1 \\
\text { (Kelingking) }\end{array}$ & $\begin{array}{c}\text { Tidak } \\
\text { Dikenali }\end{array}$ & $\begin{array}{l}\text { Stabil } \\
\text { Akurat }\end{array}$ \\
\hline 3 & 2 & Dua & $\begin{array}{l}\text { Stabil } \\
\text { Akurat }\end{array}$ \\
\hline 4 & 3 & Tiga & $\begin{array}{l}\text { Stabil } \\
\text { Akurat }\end{array}$ \\
\hline 5 & 4 & Empat & $\begin{array}{l}\text { Stabil } \\
\text { Akurat }\end{array}$ \\
\hline
\end{tabular}

Pada skenario pengujian 11, deteksi hand gesture berjalan stabil dan akurat sesuai output pada semua hand gesture, ternyata posisi jari tangan yang terbuka secara acak tidak mempengaruhi keberhasilan dalam mendeteksi bentuk isyarat tangan pengguna dikarenakan sistem masih dapat mengenali bentuk isyarat tangan sesuai dengan output.

\section{KESIMPULAN DAN SARAN}

Dari hasil dan pembahasan mengenai Hand Gesture Recognition menggunakan metode Convex Hull dan Convexity Defects, dapat disimpulkan yaitu :

1. Sistem dapat menerjemahkan dan mengubah hand gesture dari pengguna menjadi bahasa yang sesuai dengan output.

2. Proses mendeteksi hand gesture dapat dilakukan oleh webcam yang terintegrasi melalui laptop pengguna sehingga dapat dimaksimalkan fungsinya, namun webcam tetap memiliki kelemahan pada bagian resolusi dan sensor. 
3. Metode Convex Hull dan Convexity Defects terbukti stabil dan akurat dalam mendeteksi dan menerjemahkan isyarat tangan pengguna.

4. Variabel jarak antara tangan pengguna dengan webcam, background dan kondisi cahaya turut mempengaruhi kestabilan dan keakuratan dalam mendeteksi tangan pengguna.

5. Jarak tangan dengan webcam dapat dideteksi dengan stabil dan akurat apabila dalam jangkauan antara 50 $\mathrm{cm}-70 \mathrm{~cm}$.

6. Kondisi cahaya yang stabil dan akurat dalam mendeteksi isyarat tangan apabila kondisi cahaya antara 152 lux - 460 lux.

7. Sudut jari tangan yang stabil dan akurat dalam mendeteksi isyarat tangan apabila terbentuk sudut jari tangan antara $25^{\circ}-70^{\circ}$.

8. Kondisi background yang stabil dan akurat dalam proses deteksi isyarat tangan apabila dalam keadaan polos dan tidak sewarna dengan tangan pengguna.

Saran yang perlu diperhatikan dari penulis untuk penelitian lebih lanjut adalah :
1. Output dari pengenalan isyarat tangan pengguna sebaiknya dapat divariasikan ke bentuk bahasa lainnya.

2. Media pendeteksi hand gesture agar dapat divariasikan ke kamera input lainnya yang memiliki resolusi dan sensor yang lebih baik daripada webcam.

3. Pada penggunaan metode atau algoritma, sebaiknya perlu ditambahkan atau diperbarui sehingga dalam mendeteksi isyarat tangan pengguna dapat dilakukan lebih mudah, akurat dan stabil.

4. Objek tangan pada penelitian ini dapat dikembangkan menggunakan objek lain seperti wajah, tubuh, atau bagian tubuh lainnya yang memungkinkan.

5. Warna kulit pada objek tangan pengguna dapat diteliti lebih lanjut sesuai dengan varian warna kulit tangan pengguna dari seluruh dunia.

\section{DAFTAR PUSTAKA}

Arikunto, S. 2002. Prosedur Penelitian Suatu Pendekatan Praktek. Jakarta: Rineka Cipta.

Chen, W. Z. 2011. Real-Time Palm Tracking and Hand Gesture Estimation Based on Fore-Arm Contour. Tesis. Department of 
Computer Science and Information Engineering, University of Science and Technology. Taiwan.

Lukito, Y., Harjoko, A. 2013. Pengenalan Hand Gesture Dinamis Menggunakan JST Metode Pembelajaran Backpropagation. Seminar Nasional Ilmu Komputer FMIPA UGM, Oktober 2013.

Muqtadir, A., Pramono, B., \& Ningrum, I. P. 2016. Pengendali Fungsi Pointer Berbasis Hand Gesture Menggunakan Algoritma Convex Hull. semanTIK, Vol.2, No.1, pp. 141-154, ISSN : 2502-8928 (Online), Jan-Jun 2016.

Rakibe, R. S., Patil, B. D. 2013. Background Subtraction Algorithm Based Human Motion Detection. International Journal of Scientific and Research Publications, ISSN 2250-3153, Volume 3, Issue 5, May 2013.

Sugiyono. 2012. Metode Penelitian Kuantitatif Kualitatif dan $R \& D$. Bandung: Alfabeta. 